\title{
The gluten enteropathy in East Slovakia
}

\author{
Gabriela Harvanová, Silvia Duranková, Alexander Csanády \\ Department of Biology, Faculty of Humanities and Natural Sciences, University of Prešov, Prešov, Slovakia
}

\section{ABSTRACT}

Celiac disease is characterized as an autoimune disorder, and the trigger is gluten delivered into the body in a meal. The main purpose of the study was the issues about gluten enteropaty in East Slovakia, based on special scientific and foreign literature which was avaliable, also there are characteristics about digestion, celiac disease and gluten, critical factors and also premiss beginners of celiac disease. The research, which is discussed at the end of the thesis, was conducted in East Slovakia, namely in the gastroenterologic ambulance in the Humenné town. The above-mentioned research brought us information about the current position of celiac disease between different ages in the Humenné region. Our main aim was to find out whether there is any significant correlation between the age and risk of involvement of celiac disease.

\section{KEY WORDS}

celiac disease, gluten enteropathy, Slovakia.

\section{ADDRESS FOR CORRESPONDENCE \\ Silvia Duranková, Department of Biology, Faculty of Humanities and Natural Sciences, University of Prešov, Prešov, Slovakia, e-mail: silvia.durankova@unipo.sk}

\section{INTRODUCTION}

The number of patients suffering from celiac disease (CD) constantly increases. According to many scientific studies, CD can be described as a lifelong disease that causes serious gastrointestinal problems, but does not endanger the lives of patients. It can occur in childhood or in the later ages till the geriatric stadium. For elimination of this disease it is important to adhere to a gluten-free diet prescribed by a gastroenterologist $[1,2]$. This diet is the only known treatment for now, but sometimes it is very expensive and not available everywhere. According to various world surveys, some patients indicate that after eliminating gluten from meals, their condition has improved. However, there are still many patients suffering from $\mathrm{CD}$ and do not follow a diet which is recommended by their gastroenterologists, and this is the reason why their health problems continue. Suffering from gluten intolerance or $\mathrm{CD}$, the body automatically produces the antibodies, because it considers gluten as a dangerous foreign ingredient. Trying to remove gluten leads to damage to the villi and mucosa of the small intestine, resulting in malabsorption of nutrients. This can be the reason for other disease connected with malabsorption of the 
nutrients such as e.g. tumour diseases, avitaminosis and others [3]. Celiac disease does not only affect the digestive system, but also the dental, dermal and reproductive systems. Sometimes it can lead to serious problems like infertility in both females and males [4]. There are also many risk factors, including genetic predisposition, that affect the origin of disease [5].

The aim of this study was to introduce statistic results of the survey made in East Slovakia (Humenné district).

\section{CASE REPORT}

According to the medical dictionary, the $\mathrm{CD}$ can be defined as a serious autoimmune disease of the digestive system which destroys the villi of the small intestine and interferes with the absorption of nutrients from food [6]. As shown in the figure below, there is a difference between healthy and destroyed small intestine, which suffers from CD (Figure 1).

The research was conducted by anonymous multiple choice questionnaires, which were given for patients to complete during the visit to a gastroenterology ambulance in the Humenné town. Before the final publication of the questionnaire, a pilot survey was made, which was attended by 8 people and which helped us to improve our question strategy. According to their comments and suggestions, we have prepared the final form of the questionnaire. A total of 150 anonymous questionnaires were completed. The research comprised 11 men and 139 women completing the questionnaires. Questionnaires were filled in voluntarily and patients signed consent to the publication.

The biggest number of respondents was in 26-45 years category, the average height for men was $180 \mathrm{~cm}$ and $167 \mathrm{~cm}$ for women for the category of 25 years and less. The average body weight was for men $80 \mathrm{~kg}$ and for women $64 \mathrm{~kg}$. According to the body mass index (BMI), the average value for women was $22.9 \mathrm{~kg} / \mathrm{m}^{2}$, which means optimum and there were no signs of malnutrition or overweight. The average BMI in men was $24.7 \mathrm{~kg} / \mathrm{m}^{2}$, which was also optimal.

As the research shows, CD manifests after the age of 20 in $27 \%$ of men and women population. The second most frequent age for manifestation is 20 years and less (11-20-year-old patients mostly).

The most common symptoms were recorded e.g. gastrointestinal problems like cramps or inflated stomach. According to the definition of $\mathrm{CD}$, these symptoms are relevant to the disease concluding the villus to be destroyed.

We found a statistically significant correlation, or a statistically significant difference between the variables. We examined variables such as the gender and age of respondents in relation to dietary adherence and improvement of the health condition under the influence of diet, the influence of gender on satisfaction with the choice of gluten-free foods, recommended selection of medical examinations such as histological examination, per rectum, biopsy, gastrofibroscopic examination, use of probiotics and awareness of respondents. Data were statistically evaluated in nonparametric statistics using the Spearman correlation coefficient and using the Kruskal-Wallis test, which is an extension of the Mann-Whitney test for several variables. The aim of the test was to reveal whether the differences in medians of individual groups found in the sample were statistically significant, indicating a relationship between the variables.

Based on the Spearman correlation coefficient, the correlation was confirmed. $P$ is less than the statistically
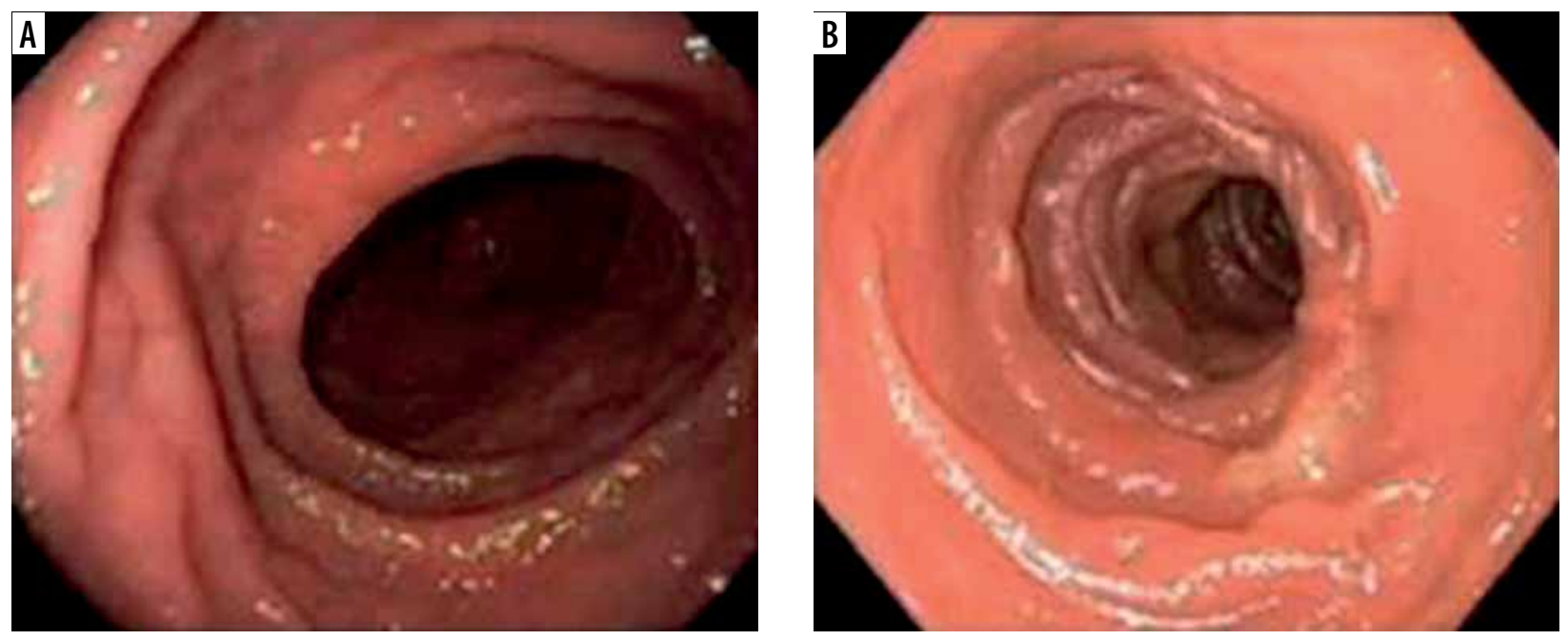

FIGURE 1. Endoscopic small intestinal biopsy for diagnosis of celiac disease: A - scalloping, mosaic pattern, nodularity, B - normal, smooth, velvetine mucosa) (source: https://www.films.com/ecTitleDetail.aspx?TitlelD=32722) 
determined level for significance in the correlation. There was a positive correlation between the body height and body weight of the respondents (Table 1).

We assumed a statistically significant correlation between individual examinations, which were not made. Based on Table 2 below, we can conclude that there is a statistically significant correlation between histological and gastrofibroscopic examination and rectal examination and recommendation to have a biopsy of the small intestine.

We assumed a statistically significant correlation between individual sources of information in relation to $\mathrm{CD}$. We investigated whether there were statistically significant correlations among the awareness of our respondents. Based on Table 3 below, we can conclude that there is a statistically significant correlation between individual variables and patients to be informed of $\mathrm{CD}$ by a doctor concluding explanation of the biopsy term and the doctor's procedure.

\section{DISCUSSION}

Awareness of CD is important not only for people with the disease, but also for readers who are not familiar with the important concepts and the meaning of gluten in $\mathrm{CD}$. Several studies point to the urgent need to promote awareness of the meaning of CD, especially in atrisk groups. It is important to know the symptoms of CD, the right screening methods and the need to confirm the diagnosis by a small bowel biopsy [7].

The survey has been made, but it only covered patients with $\mathrm{CD}$ who responded to various issues related to gluten enteropathy. The questions focused on the patients' awareness about this disease, various symptoms, intervals of medical examinations and examinations performed. Gluten enteropathy is a widespread disease that causes problems in the digestive system, it can even lead to complications related to other systems such as the reproductive system [8].

According to results of our survey, we found out that $\mathrm{CD}$ occurs mainly after the age of twenty in women, but in men it occurs in the range from the seventh to the tenth year of life. We compared our results to the research conducted in Northern Europe, where CD was found most often in range of tenth and the fortieth year of life [9]. We found out that CD occurs mainly in females, and we also compared our results to the research performed by Lima et al. [10], who reported that mostly women suffer from $\mathrm{CD}$. All respondents answered the question of whether they are familiar with the concept of $\mathrm{CD}$ and function of gluten in the body. Based on this, we can evaluate that patients have good awareness.
TABLE 1. Body height and body weight of patients

\begin{tabular}{|l|c|}
\hline Variable & $\begin{array}{c}\text { Spearman correlation } \\
\text { coefficient }\end{array}$ \\
\hline Body height - body weight & Correlation $=0.327996$ \\
\hline Confirmation/rejection of hypothesis & $\begin{array}{c}\text { Hypothesis has been } \\
\text { confirmed }\end{array}$ \\
\hline
\end{tabular}

TABLE 2. Connection between different examinations connected to $C D$

\begin{tabular}{|l|c|}
\hline Variable - type of examination & $\begin{array}{c}\text { Spearman correlation } \\
\text { coefficient }\end{array}$ \\
\hline $\begin{array}{l}\text { Gastrofibroscopic - histological } \\
\text { examination }\end{array}$ & Correlation $=0.206866$ \\
\hline $\begin{array}{l}\text { Rectal examination - biopsy of the } \\
\text { small intestine }\end{array}$ & Correlation $=0.278984$ \\
\hline Confirmation/rejection of hypothesis & $\begin{array}{c}\text { Hypothesis has been } \\
\text { confirmed }\end{array}$ \\
\hline
\end{tabular}

TABLE 3. Patients to be informed about $C D$ in connection with explanation of the doctor's procedure or terminology

\begin{tabular}{|l|c|}
\hline Variable - information sources & $\begin{array}{c}\text { Spearman correlation } \\
\text { coefficient }\end{array}$ \\
\hline $\begin{array}{l}\text { Explanation the biopsy term/ } \\
\text { terminology } \\
\text { Patients to be informed about CD by } \\
\text { a doctor }\end{array}$ & Correlation $=0.230123$ \\
\hline $\begin{array}{l}\text { Explanation of the doctor's procedure } \\
\text { Patients to be informed about CD by } \\
\text { a doctor }\end{array}$ & Correlation $=0.166667$ \\
\hline Confirmation/rejection of hypothesis & $\begin{array}{c}\text { Hypothesis has been } \\
\text { confirmed }\end{array}$ \\
\hline
\end{tabular}

As to the most common symptoms that have led to $\mathrm{CD}$, respondents indicated that cramps and bloated stomach were the most serious problems. These symptoms occurred to a large extent in both sexes. According to the research by Bardella et al. [11], clinical signs are more common in men than in women.

The largest percentage is represented by patients who showed general difficulties (fatigue, weight loss...) $22 \%$. The second most common option chosen by $14 \%$ of respondents was gastrointestinal problems (diarrhoea, vomiting, bloating, constipation). Concomitant diseases developed in patients with these symptoms such as osteoporosis, avitaminosis and others. As we expected, the most common concomitant disease was anaemia (20\% of respondents), then osteoporosis (12\% of respondents). According to Gujral et al. [12], co-morbidities occur in about $50 \%$ of the patients worldwide. 


\section{CONCLUSIONS}

We highlighted the importance of terminology about $\mathrm{CD}$ and examinations which patients undergo. We proved a statistically significant correlation between awareness of patients and examinations or between body height and body weight in people suffering from CD. Also, we compared the symptoms in our results with the results of worldwide research. The $\mathrm{CD}$ is a serious autoimmune disorder and it is necessary to know the symptoms and procedure important for the patient's health.

\section{CONFLICT OF INTEREST}

The authors declare no conflict of interest.

\section{REFERENCES}

1. Parzanese I, Qehajaj D, Patrinicola F, et al. Celiac disease: from pathophysiology to treatment. World J Gastrointest Pathophysiol 2017; 8: 27-38.

2. Khatri M. Celiac Disease: Symptoms, Gluten in Foods, Gluten Allergy Tests, and More. 2018; https://www.medicinenet.com/celiac_disease_pictures_slideshow/article.htm

3. Alphamedical, Postavenie a význam mikroskopickej (biopsie) a imunologickej diagnostiky v oblasti gastroenterológie. 2016; https://www.alphamedical.sk/casopis-invitro/postavenie-vyznam-mikroskopickejbiopsie-imunologickej-diagnostiky-v-oblasti

4. Stazi AV, Mantovani A. Celiac disease. Risk factors for women in reproductive age. Minerva Ginecol 2000; 52: 189-96.

5. Kagnoff MF. Celiac disease: pathogenesis of a model immunogenetic disease. J Clin Investig 2007; 117: 41-9.

6. Mayoclinic. Celiac Disease. 2019; https://www.mayoclinic.org/diseases-conditions/celiac-disease/symptoms-causes/syc-20352220

7. Adams S. Celiac Disease Awareness Low According to Pediatric Gastroenterologist Survey Results. 2005; http://www.celiac.com/ articles/886/1/Celiac-Disease-Awareness-LowAccordingtoPediatric-Gastroenterologist-Survey-Results/Page1.html

8. Shiel W. Medical definition of Gluten enteropathy. 2018; https:// www.medicinenet.com/script/main/art.asp?articlekey $=3614$

9. Akhondi H, Ross AB. Gluten and associated medical problems. StatPearls 2020; https://www.ncbi.nlm.nih.gov/books/NBK538505/

10. Lima RF, da Silva Kotze LM, Kotze LR, et al. Gender-related differences in celiac patients at diagnosis. Arch Med Res 2019; 50: 437-41.

11. Bardella MT, Fredella C, Saladino V, et al. Gluten intolerance: gender-and age-related differences in symptoms. Scand J Gastroenterol 2005; 40: 15-9.

12. Gujral N, Freeman HJ, Thomson AB. Celiac disease: prevalence, diagnosis, pathogenesis and treatment. World J Gastroenterol 2012; 18: 6036. 